\title{
The Effect of William Flexion Exercise on Low Back Pain in Traditional Weaving Workers in The Village of Sidemen Karangasem
}

\author{
A A Gede Saska A ${ }^{1}$, Made Rini Damayanti $\mathrm{S}^{2}$, Komang Menik Sri Krisnawati ${ }^{3}$ \\ School of Nursing \\ Medical Faculty, Udayana University \\ Denpasar, Bali \\ ariputra_saska@yahoo.com \\ Community Nursing Department, \\ School of Nursing, Medical Faculty, Udayana University \\ Denpasar, Bali \\ Nursing Management Department \\ Medical Science Faculty, Udayana University \\ Denpasar, Bali
}

\begin{abstract}
Low back pain (LBP) is a subjective sensation characterized by a major symptom of pain in the lower spine region. One of the basic causes is the stress inflicted on the inter-vertebral disk due to poor posture, so that the lumbar spine of the lumbar lordosis has too much strain on the posterior element. These complaints usually occur in workers due to incorrect posture or work position that does not meet the ergonomic principles of one of the traditional weavingworker. Exercise has been widely developed to cope with LBP such as stretching and muscle strengthening. William's flexion exercise (WFE) is an exercise aimed at stretching the posterior muscles and strengthening the abdominal muscles so that the tendon and spongy muscles are expected to relax. The purpose of this study is to determine the effect of WFE on LBP on traditional weaving workers. This study is a preexperimental study (One-Group Pretest-Posttest Design). The sample consists of 28 respondents selected by using Purposive Sampling technique. Data collected by using questionnaires for respondent characteristics and Numeric Rating Scale for measuring pain scale before and after intervention. The result of the research before intervention was $75 \%$ of respondents had moderate pain, while after intervention $85.7 \%$ of respondents had mild pain. Based on the Wilcoxon test results obtained $\mathrm{p}=$ 0.000 which means there is the influence of WFE on LBP on traditional weavingworker. Based on the above research, it is suggested to health workers teach WFE in order to reduce LBP on traditional weavingworkers.
\end{abstract}

\section{Index Terms — Low back pain,Traditional weaving worker, William's flexion exercise}

\section{INTRODUCTION}

Pain is an unpleasant sensation that can be felt in each individual in the form of sensory and emotional experiences that indicate tissue damage [9]. One pain that is often complained about by individuals is lower back pain [2]. Lower back pain (LBP) is the main symptom of pain in the lower lumbar region [7]. One of the basic causes is stress generated on the inter-vertebral disk because of poor posture [4]. This complaint usually occurs in workers due to incorrect posture when lifting weights and working positions that do not meet ergonomic principles.

Low back pain because the work done by a person can be categorized into Occupational Disease (PAK) which is often reported by companies [10]. Data from the Ministry of Health of the Republic of Indonesia in 2012 stated that the number of PAK cases in Indonesia was lower than 450 thousand people, upper lumbar or cervical 426,000 cases, and extremities namely 224,000 cases (Ministry of Health of the Republic of Indonesia, 2012). At present $90 \%$ of cases of lower back pain found in workers are not caused by physical abnormalities, but by the lack of proper position of one's work [12].

Workers who have LBP risk are individuals with less ergonomic positions and work methods such as rickshaw pullers, tea leaf pickers, telephone operators, and traditional weaving workers [18]. Weaving activities in addition to requiring hand skills, also require traditional weavers to maintain extreme flexi positions for a long time. Body posture and how to work less ergonomically or beyond that resistance can be a cause of LBP [14]. 
Various interventions to prevent and reduce low back pain have been developed through research. More nonpharmacological interventions are recommended to be used than pharmacological interventions to reduce pain in the form of exercise. Exercise has been widely developed to cope with lower back pain such as stretching, low impact aerobic exercise, and muscle strengthening such as William flexion exercise [4].

Based on the literature review obtained, researchers focused on conducting research into the effect of WFE on LBP on traditional weaving workers in the Sidemen Village of Karangasem.

\section{METHOD}

This research is a experiment using the OneGroup Pretest Posttest Design approach to find out the effect of WFE on LBP on traditional weaving workers in Sidemen Karangasem Village in 2018.

The population of the study was 30 Swastika Ikat Weaving workers in Sidemen Village, all of whom had female gender. The way to take samples with Non Probability Sampling is Purposive Sampling using the Slovin formula after the inclusion and exclusion criteria according to the sample size of 28 people. Data collection was done using a pain measuring device in the form of a scale of the Numeric Rating Scale (NRS) which was measured before and after intervention. The william flexion exercise (WFE) guide uses the WFE check list in the form of seven movements [4].

\section{Data Procedure and Analysis}

The researcher selected 28 respondents who met the inclusion criteria, namely the research subjects who were willing to be respondents, who experienced low back pain with a mild to moderate scale, $\mathrm{BMI} \leq 25$. Exclusion criteria for this sample were uncooperative or unwilling to follow the entire study series, suffering from diseases (spinal cancer, spondylisthesis), using analgesic drugs, having postural abnormalities such as scoliosis, exercising regularly at least once every two days, active smokers, having a history of trauma and chronic congenital conditions.

This study began by measuring the demographic characteristics of the response and assessing the scale of pain before intervention using NRS. WFE exercises were given to respondents three times a week for three weeks and the scale of lower back pain was measured using NRS on the last day of the third week after exercise. Descriptive testing is used to identify respondent characteristics andpain scale before and after intervention. The Wilcoxon Test with a 95\% significance level $(\mathrm{p}<0.05)$ was used to determine the effect of WFE on LBP on traditional tie weaving workers.

\section{RESULt}

Characteristic data of research samples are presented in the table below.
TABLE I

RECAPITULATION OF RESPONDENT DATA

\begin{tabular}{lcc}
\hline \hline \multicolumn{1}{c}{ Many } & Categories (F) & $\begin{array}{c}\text { Percent } \\
(90)\end{array}$ \\
\hline $\begin{array}{l}\text { Gender } \\
\text { Male }\end{array}$ & 0 & 0 \\
Female & 28 & 100,0 \\
\hline Total & 28 & 100,0 \\
\hline Age (Years) & 7 & 25,0 \\
$45-50$ & 6 & 21,4 \\
$51-55$ & 9 & 32,2 \\
$56-60$ & 6 & 21,4 \\
$61-65$ & 28 & 100,0 \\
\hline Total & & \\
\hline Working Period (Years) & & 82,1 \\
$6-10$ & 23 & 17.9 \\
$>11$ & 5 & 100.0 \\
\hline Total & 28 & 53,6 \\
\hline BMI & & \\
$18,5-22,9$ (normal) & 15 & 46,4 \\
$23,0-24,9$ (at risk of & 13 & 100,0 \\
obesity) & & \\
\hline Total & 28 & \\
\hline \hline
\end{tabular}

The above data shows the sample characteristics of all women are as many as 28 people. Most respondents in this study were in the age group of 56 to 60 years, namely nine people $(32.2 \%)$. Most respondents have a working period of six to ten years, namely 23 people $(82.1 \%)$. The results of this study present more than half of the respondents ( 15 or $53.6 \%$ ) were in the normal category or had a BMI range between 18.5 and 22.9 .

The difference in the average value of pain scale before and after intervention can be seen in table 2 .

$$
\text { TABLE II }
$$

DESCRIPTIVE DATA OF RESPONDENTS BEFORE AND AFTER INTERVENTION AND TEST RESULTS OF THE INFLUENCE OF WILLIAM FLEXION EXERCISE

\begin{tabular}{lccccc}
\hline \hline & Mean & Min & Max & Z & p Value \\
\hline $\begin{array}{l}\text { Pre WFE } \\
\text { Pain Scale }\end{array}$ & 4,14 & 2 & 6 & & \\
\cline { 1 - 4 } $\begin{array}{l}\text { Post WFE } \\
\text { Pain Scale }\end{array}$ & 1,64 & 0 & 3 & $-4,687$ & 0,000 \\
\hline \hline
\end{tabular}

Before the WFE intervention was given, the average pain scale of respondents was 4.14 or in the moderate pain category, with a minimum pain scale value of two (mild pain) and a maximum value of six (moderate pain). After WFE intervention was given the average pain scale of respondents was 1.64 or in the category of mild pain, with a minimum value of zero (no pain) and a maximum value of three (mild pain).

The value of $p$ from the results of different tests of two pairs of samples for the effect of WFE on low back pain in traditional weaving workers in Sidemen Karangasem village was 0,000 which means $\mathrm{p}<0.05$ so $\mathrm{Ha}$ was accepted. Theseresults indicate that there was the influence of William flexion exercise onLBP on traditional weaving workers in Sidemen Village Karangasem. 


\section{DISCUSSION}

Low back pain can be experienced in all age ranges, but chronic LBP is found in a more mature age range [3]. Low back pain that is felt in the adult age group to the elderly can be reduced by exercise. According to Delitto (1993) in Tulder (2000), flexion exercise is well used in sub-acute to chronic LBP conditions to improve postural lumbar so that it has an effect on decreasing lower back pain.

The results of the study at the Swastika Tie Weaving Production House showed that there was a significant effect between WFE on the decrease in the scale of lower back pain in traditional weaving workers in the Sidemen Village of Karangasem. The results of this study are in line with the research conducted by Sa'adah in 2013 in his study which stated that there was a significant effect of WFE on the level of lower back pain in the elderly at the posyandu for the elderly. This study uses respondents with the age category of elderly who complain of LBP. Lower back pain in the elderly will be greater with a non-ergonomic work position.

The scale of moderate pain experienced by many traditional weaving workers in Sidemen Karangasem village is likely because the worker is doing activities sitting in a static position or fixed without changing positions. The statement is in line with the theory of Tarwaka (2004) states that when working in a sitting position continuously it will cause muscle contraction to become static and the load pattern in one muscle becomes stronger compared to dynamic contraction.

Static position in the research subjects of traditional weaving workers in the Sidemen village of Karangasem is to sit stretched for a long time. The long sitting position causes the lumbar muscel to continue to contract so that it will affect the soft muscel around it. This is in line with the research conducted by Nurlaily (2016) who examined the effectiveness of WFE on LBP functional mechanics in garment workers found that complaints of lower back pain were felt more by finishing garment workers who did their jobs in seated seats on the floor within eight hour. Sitting on the floor for long periods of time will cause a thrust in the lumbar nerve pads which results in pinching the lumbar nerve between the lumbar passages so that it can cause LBP and also cramps that radiate to the thigh to the calves [14]. This condition will be more pronounced if done by workers in a long working period.

According to Hendra and Suwandi (2009) workers who have five years of work more cause bone and muscle pain disorders compared to workers with a work period of less than four years as much as three times greater. The same pattern occurs in traditional weaving workers in Sidemen Karangasem Village, this condition is due to the durability of muscel used in activities can decline as long as individuals move. WFE can be given to workers who have a long working period. According to a study conducted by Tulder (2000), effective WFE was given to chronic LBP patients caused by one of the lengths of a person's work period. WFE can also have the effect of muscel flexibility and stiffness that works synergistically, from a collection of abdominal and pelvic muscel [4].

The results of this study found that almost half of the respondents were in the category of at risk of obesity. The increase in BMI results in reduced muscel tone, hence the center of gravity can go towards the front of the body and result in an increased lumbar lordosis posture. Changes in posture can cause fatigue in paravertebral muscles [13]. WFE can be used to overcome the urge by body weight to join and tighten the muscles and fascia in the lumbar back area, and also serves to improve the body's position is not correct, this exercise can also improve the lumbar balance because it continuously uses the abdominal muscel, gluteus maximal and leg muscles [1].

Movements in WFE therapy can activate the structure between the vertebral bones, reduce the shape of the joint and relax the apophyseal joint. Movement when the pelvic front is down and the pelvic back rises which causes the flexor hip to shorten and the extensor hip extends (pelvic tilt) is useful for strengthening the supporting muscles around the lower lumbar, especially the abdominal muscles. The second exercise is single and double knee to chest, which is to move one to both knees towards the chest as far as possible, and both hands reach the hamstrings useful for the elasticity of the lower lumbar muscles. Floating leg exercises that are movements with one leg raised in a straight knee position pointing straight up which is useful for correcting the lower lumbar muscles and hamstring muscles. Partial sit-up movements, namely the bending of the head, so that the chin touches the chest aims to reduce lumbar lordosis [4].

The effect of WFE on reducing the scale of lower back pain can be attributed to the amount of metabolic waste accumulated in tissues such as bradykinin, prostaglandins, potassium ions, serotonin, $\mathrm{P}$ histamine substances, and lactic acid buildup due to circulatory system problems, muskeltissue, and nerves [9]. The remaining blood circulation can be reduced by the WFE movement which functions to dilate blood vessels. This activity can improve the transport of oxygen to blood vessels that experience stiffness, because pain can be overcome [8].

The WFE in this study was conducted in groups. Exercise carried out in groups has the advantage that someone will be excited and more active because many are involved in taking part in the training, but have the disadvantage that the individual must match the hours of exercise with the agreed training agreement [15]. This study was supported by Yuliantini (2015) who obtained WFE results more effectively reducing lower back pain than individual stretches. According to Turner (1997), togetherness is one of the factors that can increase the willingness of the elderly to be able to exercise so that in doing the exercises the elderly feel comfortable and happy which in turn can reduce the pain that is felt.

According to Kravitz (2006) individuals who experience low back pain for a period of three years if they don't do WFE can risk twelve times for back pain. WFE, which is 
routinely carried out at least once every two days, is a good exercise to improve muscel and strengthen muscel so as to reduce the possibility of injury again [6].

\section{CONCLUSION}

The results of the analysis of the influence of WFE on the level of decline in low back pain in traditional weaving workers in Sidemen Karangasem village with the Wilcoxon Test statistical test obtained a $\mathrm{p}$ value of $0,000(\mathrm{p}<0.05)$ so that Ha was accepted so that there could be WFE influence on the level of decrease in back pain down to traditional weaving workers in Sidemen Village Karangasem.

Weaving workers are expected to continue to practice WFE regularly at least once every two days to provide good benefits and reduce lower back pain. Further research can be done in different settings with work positions that are not ergonomic or have the risk of lower back pain or involving a control group. These results should be used as guidelines by business owners in improving the health status of workers aimed at workers who carry out work processes in a non-ergonomic sitting position. The government in this case the Puskesmas is expected to improve health promotion programs and improve the Occupational Health Business (UKK) program, specifically Occupational Health and Safety

\section{REFERENCES}

[1] Andryanto, Winaya, N.,\& Silakrama, D. "Intervensi William Flexion Exercise Lebih Baik dari Massage pada Kombinasi IR dan Tens untuk Penurunan Nyeri Penderita Spondilosis Lumbal 2013". Program Studi Fisioterapi Fakultas Kedokteraan Universitas Udayana.2013.

[2] Bull, E.,\& Archard, G. "Simple Guide: Nyeri Punggung. Dialihbahasakan oleh Juwalita Surapsari.". Editor: Rina Astikawati dan Amalia Safitri. Jakarta: Erlangga. 2007.

[3] Harsono. "Kapita Selekta Neurologi Edisi kedua". Yogyakarta: Gadjah Mada University Press. 2009.

[4] Houglum, P.A. "Therapeutic Exercise for Musculoskeletal Injury (4th ed)". :Human Kinetic. 2016.

[5] Kisner, C. "Back Exercises Refrences Summary. the Patient Education Institute". Inc. Therapeutic Exercise Foundation And Techniques. Fifth Edition. Philadelphia: F.A. Davis Company. 2007.

[6] Kravitz. "Low Back Stability Training". Available from: www.unm.edu/ lkravitz/pages, diakses tanggal 5 Januari 2018. 2018.

[7] Kuntono, H.P. 2007. Penatalaksanaan Fisioterapi pada Kondisi Osteoarthritis. Temu Ilmiah IFI : Kediri.

[8] Laili, N. "Perbedaan Tingkat Nyeri Haid (Dismenore) sebelum dan sesudah senam dismenore pada remaja putri di SMAN 2 Jember". Skripsi. Program Studi Ilmu Keperawatan Universitas Jember. 2012.

[9] Mangku, G.,\& Senapathi, T,G.A. "Buku Ajar Ilmu Anestesia dan Reanimasi". Jakarta : Indeks. 2010.

[10] Natalia, L. "Analisis faktor-faktor yang mempengaruhi tingkat Nyeri Pinggang Bawah". operator komputer badan koordinasi penenaman modal daerah provinsi Sulawesi Selatan 2014. Universitas Hasnuddin. Juli, 21 2017. http://repository.unhas.ac.id/../Skripsi. 2014.

[11] PSIK-FK Unud. Buku Panduan Penulisan Skripsi Edisi ke-4.2015

[12] Pratiwi. "Faktor yang Berpengaruh Terhadap Keluhan Nyeri Punggung Bawah pada Penjual Jamu Gendong". Jurnal promosi kesehatan Indonesia. Volume 4. Nomor:1. Januari 2009. April, 20 2017. http://repository.unhas.ac.id/2009.

[13] Sa'adah, H.D. "Pengaruh Latihan Fleksi William (Stretching) terhadap Tingkat Nyeri Punggung Bawah pada Lansia di Posyandu Lansia RW 2 Desa Kedungkandang Malang”. Jurnal Sain Med, Vol. 5. No. 12 Oktober 2017:56-61. http://www.kopertis7.go.id. 2017.
[14] Sama'mur, P.K. "Higiene Perusahaan dan Kesehatan Kerja". Jakarta : Gunung Agung. 2009.

[15] Sri, E.W. "Perbandingan Antara Latihan Pelvic Floor Muscle Treatment (Pfmt) Secara Individu Dan Berkelompok Terhadap Inkontinensia Urin Pada Wanita Lanjut Usia Di Panti Wredha Dharma Bakti”. Universitas Muhammadiyah Surakarta. 2010.

[16] Tulder, V., M. Malmivaara, A. Esmail, R. dan Koes, B. "Exercise Therapy for Low Back Pain". SPINE. Volume 25. 2000.

[17] Wijnhoven, A.H., De Vet, H.C.W., Smit, H.A. \& Picavet, S.J. "Hormonal and Reproductive Factors are Associated with Chronic Low Back Pain and Chronic Upper Extremity Pain in women-The MORGEN Study". Spine. 2006.

[18] Yulitania, D.D. "Perbedaan Pengaruh Peregangan Dan William Flexion Exercise Terhadap Nyeri Punggung Bawah Non Spesifik Pada Pemetik Teh Di Perkebunan Teh Jamus". April 14, 2017. http://eprints.ums.ac.id. 2017. 